\title{
Immunoexpression of P53 protein in trophoblastic diseases
}

Received: 14/1/2016
Accepted: $29 / 5 / 2016$

\author{
Sanarya M. Ali $* \quad$ Nadya Y. Ahmedi $* * \quad$ Tenya T. Abdulhameed $* * \quad$ Tara M.Shalal $* *$
}

\begin{abstract}
Background and objective: Trophoblastic diseases constitute a spectrum of tumors and tumor- like conditions characterized by proliferation of pregnancy associated trophoblastic tissue of progressive malignant potential. This study aimed to assess the value of p53 protein immunoexpression in the diagnosis of hydatidiform molar pregnancy and the differential diagnosis of its subtypes (complete and partial) from abortions.

Methods: A cross-sectional study of tissue sections from 68 formalin-fixed, paraffin- embedded specimens of products of conception, including 1st trimester abortion $(n=15)$, partial hydatidiform mole PHM $(n=24)$, complete hydatidiform CHM $(n=24)$ and full term placenta $(n=5)$, all were examined at the Histopathology Department of Maternity Teaching Hospital in Erbil, Iraq during the period of Jan.2013-Jun.2013. Immunohistochemistry was performed using p53 antibody and the standard streptavidin-biotin immunoperoxidase method. The labeling index (number of positive nuclei/total number of nuclei) for villous cytotrophoblasts, syncytiotrophoblasts and stromal cells were evaluated separately. Statistical analysis was carried out by one way ANOVA and Fisher's exact tests, statistical significance was determined at $P \leq 0.05$.

Results: All villous trophoblastic lesions showed higher p53 immunoexpression in all villous components especially cytotrophoblasts, being the highest in complete hydatidiform mole $(>50 \%)$ and partial hydatidiform mole (>20\%). A statistically significant difference was found in immunoexpressins of p53 that was useful in separating abortion from complete hydatidiformmole, $P<0.001$, and partial hydatidiform mole, $P<0.0002$. It was also useful in separating between the complete hydatidiform mole and partial hydatidiform mole $(P<0.001)$.
\end{abstract}

Conclusion: p53 immunoexpression was valuable in differentiation between molar and non molar pregnancies and between subtypes of molar pregnancies.

Keywords: Hydatidiform Mole; Abortion; p53; Immunohistochemistry.

\section{Introduction}

Gestational trophoblastic disease (GTD) is a group of conditions associated with abnormal pregnancy, histologically; it includes the benign partial and complete hydatidiform mole, invasive mole, as well as the malignant choriocarcinoma. Molar pregnancies may develop persistent elevated serum human chorionic gonadotropin (hCG) levels after evacuation (complete mole $15 \%-20 \%$, partialmole $0.1 \%-5 \%$ ), with a chance of progression to choriocarcinoma. Complete mole has florid trophoblastic proliferation, and absence of fetal parts. In contrast, such histological features are less marked in partial mole and fetal parts are present, such as fetal cells. Hydropic spontaneous abortion may mimic the appearance of partial mole. ${ }^{1}$ Choriocarcinoma is a malignant tumor with the absence of chorionic villi, abnormal syncytiotrophoblast and cytotrophoblast, necrosis, and hemorrhage. It may invade the uterus and surrounding organs and it is common to have distant spread, particularly to the lung, but it may also

* Department of Pathology, Ministry of Health, Erbil, Iraq.

** Department of Pathology, College of Medicine, Hawler Medical University, Erbil, Iraq. 
involve the liver, spleen, kidneys, bowels, and brain. $^{2}$ Accurate diagnosis and classification of $\mathrm{HM}$ is important as the risk of persistent gestational trophoblastic disease, including the CC, is significantly high. The risk of $\mathrm{CC}$ in $\mathrm{CHM}$ is $10 \%-30 \%$ and in $\mathrm{PHM}$ is $0.5 \%-5 \%{ }^{3}$ Despite well-described histopathologic criteria, the distinction of spontaneous abortion from $\mathrm{HM}$ and $\mathrm{CHM}$ from PHM remains a problem because of interobserver and intraobserver variability. ${ }^{4}$ Thus, development of new methods that allow differentiating these pathologies in doubtful cases is important. A complementary method to the pathologic interpretation is immunohistochemistery (IHC). Among the immunohistochemical markers, tumor suppressor proteins such as p53 have been investigated for this purpose. The p53 gene is important for several reasons including, genomic stability, transactivation of genes involved in cell cycle regulation, DNA repair, apoptosis, effectiveness of chemotherapy and prognosis of the disease. ${ }^{5}$ Mutation of p53 gene has been reported in a variety of human malignant tumors and is frequently associated with over expression of p53 protein. The extended half-life of mutant p53 protein allows it to accumulate to high concentration within the nuclei of affected cells, and it can be readily detected by $\mathrm{IHC}$ with antibodies specific to p53 protein; however in normal cells, p53 protein has a short intracellular half-life and such a low steady state level is usually not detectable by IHC. The immunohistochemical reactivity of $p 53$ has been demonstrated to be associated with poor prognosis in many tumors ${ }^{6}$ and $p 53$ gene mutation might be involved in the pathogenesis of trophoblastic diseases. ${ }^{7}$ This study aimed to assess the value of p53 protein immunoexpression in the diagnosis of hydatidiform molar pregnancy and the differential diagnosis of its subtypes (complete and partial) from abortions.

\section{Methods}

Sixty eight formalin-fixed, paraffinembedded tissue blocks of products of conception were chosen by simple random selection from files of pathology department of Maternity Teaching Hospital, Erbil, Iraq during the period from Jan. 2013-Jun.2013.The studied cases were categorized into the following groups: $1^{\text {st }}$ trimester abortion ( $n=15)$, PHM $(n=24)$, CHM ( $n=24)$, in addition, 5 samples of full term placenta were included as a negative control. New sections were made from the most representative tissue block which identified that contains suitable materials without necrotic and haemorrhagic areas, thick areas or overlapping areas, then stained with haematoxylin and eosin (H\&E) and histopathologicaly evaluated, another thin $4 \mu \mathrm{m}$ section done and submitted for IHC. The study was approved by the Ethical Committee of the College of Medicine, Hawler Medical University, Erbil, Iraq. Immunohistochemistry was performed using the avidin-biotin-peroxidase complex according to a previously described protocol by $\mathrm{Hsu}$ et $\mathrm{al}^{8}$ in which primarily monoclonal antibodies raised against p53 (DakoCytomation, Denmark, clone DO-7) was used and according to DakoCytomationEnVisionR+Dual link system-HRP (DAB+) staining protocol for immunostaining. With each batch of stain positive and negative control sections were incubated. Negative controls were obtained by omitting the primary antibody and by using $\mathrm{N}$-Universal negative control, positive controls tissues specimens for P53 were prepared using invasive ductal carcinoma of the breast already stained for P53 and contained more than $50 \%$ tumor cells. Positive expression of P53 gives nuclear staining of brown color. Positive cells were determined by counting 1000 tumor cells, all significantly stained cells were considered positive and divided by 10 to decide whether the case was positive, at least 10 HPF were examined (with 400x) in each case for the purpose of scoring. The p53 labeling index (LI) in abortion 
and lesions of villous trophoblasts were evaluated separately for cytotrophoblasts, syncytiotrophoblasts, and stromal cells by counting 1000 cells for each population. The distribution of p53 immunoreactivity in trophoblastic diseases were quantitatively assessed as -ve (equal or less than 10\% are positive cells) and +ve (more than 10\% are positive cells) and the positive cases were graded as: + (10-20\%); ++ (20-50\%); and +++ (more than 50\%) are positive cells.

Statistical analysis: - Data were analyzed using the statistical package for social sciences (SPSS, version 19). One way ANOVA and Tukey HSD Post-hoc tests were used to compare the means of $p 53 \mathrm{LI}$ of cytotrophoblasts, syncytiotrophoblasts and stromal cells of trophoblastic villi among different groups (CHM, PHM and Abortions). Also, the results obtained from each case groups were compared in pairs for the following parameters included in the study ( $p 53 \mathrm{LI}$ and distribution of p53 immunostaining) by means of Fischer exact test. A $P$ value of $\leq 0.05$ was considered as statistically significant, and a $P$ value $<0.01$ was considered as statistically highly significant.

\section{Results}

A total of 68 specimens of placental trophoblastic tissues were included in this study: 1st trimester abortion $(n=15)$, PHM $(n=24), \operatorname{CHM}(n=24)$ and full term placenta $(n=5)$ as a negative control. The mean age ( \pm SD) for abortion was $29.6 \pm 3.7 y r s$, range: (20 - 42); for PHM was 29.03 \pm 2.1 years, range: (20 - 40); and for $\mathrm{CHM}$ is 31.04 $\pm 3.3 \mathrm{yrs}$, range: (17 - 50). Twenty cases of them were $20-40$ years, 2 cases were below 20 years and 2 cases were above 40 years. Specific staining with mouse monoclonal anti-p53 antibody DO-7 was confined to the nuclei of cytotrophoblasts, syncytiotrophoblasts and stromal cells of placental villi (Figure 1). All full term placenta specimens showed -ve p53 immunostaining in all components of villi, while $1^{\text {st }}$ trimester abortion showed +ve p53 immunostainingwith a $\mathrm{LI}$ of $11.267 \pm 5.788, \quad 6.600 \pm 5.475,4.733 \pm 4.217$ in cytotrophoblasts, syncytiotrophoblasts and stromal cells of trophoblastic villi respectively. Molar villous trophoblastic lesions (PHM, CHM) showed variable p53 immunoexpression in cytotrophoblasts, syncytiotrophoblasts, and stromal cells. In comparison with p53 immunoexpression of

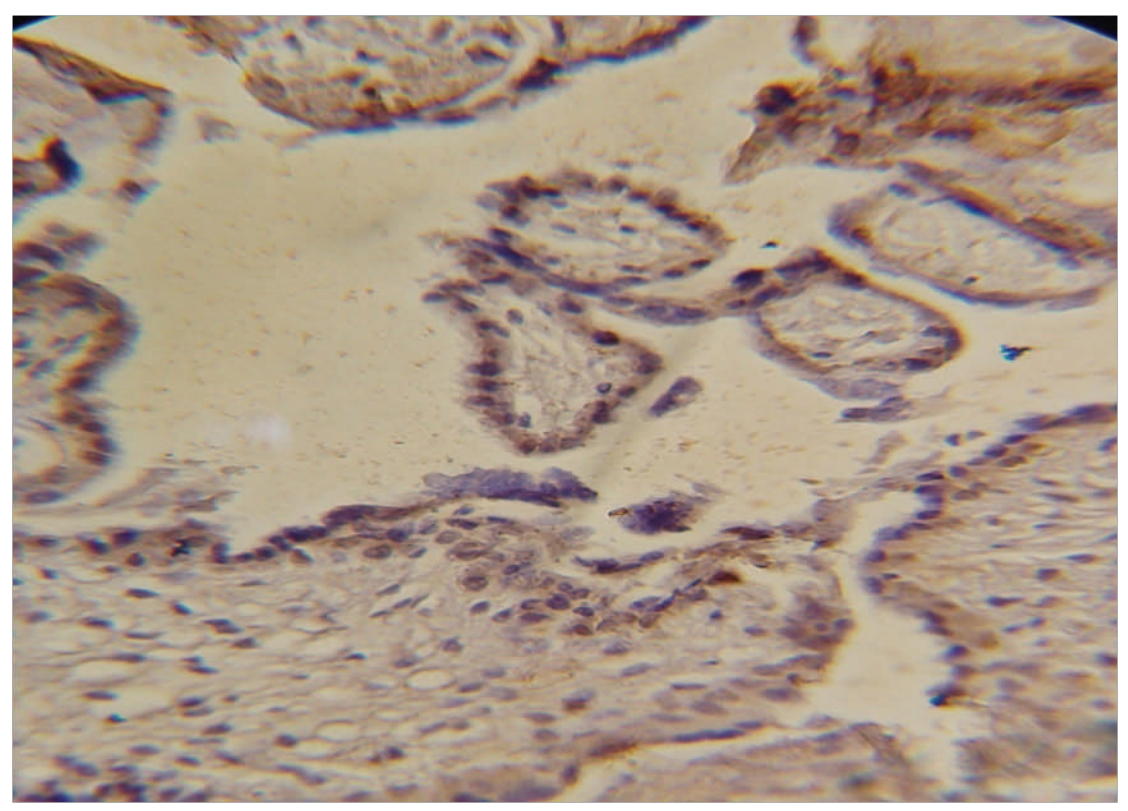

Figure 1: Focal positive P53 Immunoexpression in cytotrophoblastx400. 
$1^{\text {st }}$ trimester abortion (control group), all molar villous trophoblastic lesions showed a higher p53 expression in all villous components especially in cytotrophoblasts, being the highest in CHM (71.250 12.446$)$ followed by PHM $(29.042 \pm 14.974)$ and the lowest p53 expression observed in stromal cells of villi of PHM (13.833 \pm 9.073$)$ as shown in (Table 1). There was a statistically high significant difference between $1^{\text {st }}$ trimester abortion and molar villous trophoblastic lesions regarding p53 $\mathrm{LI}$ means in all villous components as determined by one-way ANOVA test $[\mathrm{F}(2,60)=126.196, \quad P<0.001]$ for cytotrophoblasts; $\quad[F(2,60)=107.592$, $P=0.000]$ for syncytiotrophoblasts and $[F(2,60)=87.385, P<0.001]$ for stromal tests. Tukey HSD Post hoc test shows a high statistical difference in p53 LI means of all villous components; especially cytotrophoblasts between abortion and PHM $(P=0.0002)$, abortion and CHM $(P=0.001)$ and $\mathrm{PHM}$ with $\mathrm{CHM}$ $(P=0.001)$ as shown in Table 2, 3 and 4.

Table 1: P53 Labeling index in abortion and lesions of villous trophoblasts.

\begin{tabular}{lcccccc}
\hline $\begin{array}{l}\text { Type of } \\
\text { lesion }\end{array}$ & $\begin{array}{c}\text { P53 LI in } \\
\text { cytotrophoblast }\end{array}$ & $\begin{array}{c}\boldsymbol{P} \\
\text { value }\end{array}$ & $\begin{array}{c}\text { P53 LI in } \\
\text { syncytiotrophoblast }\end{array}$ & $\begin{array}{c}\boldsymbol{P} \\
\text { value }\end{array}$ & $\begin{array}{c}\text { P53 LI in } \\
\text { Stromal } \\
\text { cells }\end{array}$ & $\begin{array}{c}\boldsymbol{P} \\
\text { value }\end{array}$ \\
\hline Abortion & $11.2 \pm 5.7$ & & $6.6 \pm 5.4$ & & $4.7 \pm 4.2$ & \\
PHM & $29 \pm 14.9$ & & $21.4 \pm 14.9$ & & $13.8 \pm 9$ & \\
CHM & $71.2 \pm 12.4$ & $<0.001$ & $61.8 \pm 12.9$ & $<0.001$ & $45.2 \pm 13.7$ & $<0.001$ \\
\hline
\end{tabular}

Table 2: Differences in p53 LI means of villous components between abortion and PHM.

\begin{tabular}{lcccc}
\hline $\begin{array}{l}\text { Type of } \\
\text { lesion }\end{array}$ & $\begin{array}{c}\text { P53 LI in } \\
\text { Cytotrophoblast }\end{array}$ & $\begin{array}{c}\text { P53 LI in } \\
\text { syncytiotrophoblast }\end{array}$ & $\begin{array}{c}\text { P53 LI in } \\
\text { Stromal cells }\end{array}$ & P value \\
\hline Abortion & $11.2 \pm 5.7$ & $6.6 \pm 5.4$ & $4.7 \pm 4.2$ & $<0.0002$ \\
PHM & $29 \pm 14.9$ & $21.4 \pm 14.9$ & $13.8 \pm 9$ & \\
\hline
\end{tabular}

Table 3: Differences in p53 LI means of villous components between abortion and CHM.

\begin{tabular}{lcccc}
\hline $\begin{array}{l}\text { Type of } \\
\text { lesion }\end{array}$ & $\begin{array}{c}\text { P53 LI in } \\
\text { Cytotrophoblast }\end{array}$ & $\begin{array}{c}\text { P53 LI in } \\
\text { syncytiotrophoblast }\end{array}$ & $\begin{array}{c}\text { P53 LI in } \\
\text { Stromal cells }\end{array}$ & P value \\
\hline Abortion & $11.2 \pm 5.7$ & $6.6 \pm 5.4$ & $4.7 \pm 4.2$ & $<0.001$ \\
CHM & $71.2 \pm 12.4$ & $61.8 \pm 12.9$ & $45.2 \pm 13.7$ & \\
\hline
\end{tabular}

Table 4: Differences in p53 LI means of villous components between PHM and CHM.

\begin{tabular}{lcccc}
\hline $\begin{array}{l}\text { Type of } \\
\text { lesion }\end{array}$ & $\begin{array}{c}\text { P53 LI in } \\
\text { Cytotrophoblast }\end{array}$ & $\begin{array}{c}\text { P53 LI in } \\
\text { syncytiotrophoblast }\end{array}$ & $\begin{array}{c}\text { P53 LI in } \\
\text { Stromal cells }\end{array}$ & P value \\
\hline PHM & $29 \pm 14.9$ & $21.4 \pm 14.9$ & $13.8 \pm 9$ & $<0.001$ \\
CHM & $71.2 \pm 12.4$ & $61.8 \pm 12.9$ & $45.2 \pm 13.7$ & \\
\hline
\end{tabular}


Regarding the distribution of p53 in abortion and villous lesions: Nine out of 15 $(60 \%)$ of first trimester abortion had p53 expressions below $10 \%$ and all of them (15 cases, 100\%) their p53 expressions were $\leq 20 \%$ in all cytotrophoblasts, syncytiotrophoblasts and stromal cells. All (24) cases of CHM (100\%) showed +ve p53 immunoexpression in all villous components with a value above $50 \%$, For PHM, 19/24 (80\%) cases had p53 expression between (10\%-50\%) in cytotrophoblasts; only one case of PHM $(5 \%)$ had p53 immunreactivity above $50 \%$. In order to study the role of p53 immunoexpression in differentiating these trophoblastic lesions, the data of these three groups (PHM, CHM, and abortion) were analyzed, matched in pairs and evaluated to their p53 expressions and the result of statistical analysis are summarized in Table (5). A highly significant statistical difference present between p53 expression of all villous components of abortion and CHM $P<0.01$; also significant differences between p53 immunoexpression of all villous components of abortion and PHM and those of PHM and CHM $P<0.05$.

\section{Discussion}

Gestational trophoblastic diseases are defined as a spectrum of abnormal gestations and neoplasms arising from villous or extra villous trophoblasts that are associated with pregnancy. It takes several forms, each with its own risk of mortality and responsiveness to chemotherapy. Differential diagnosis of these diseases by routine histopathologic examination can be challenging. Studies have recently shown that IHC for various markers is useful for confirming the diagnosis and is a complementary method to pathologic interpretation..$^{9}$ In this study, the mean age of patients with molar pregnancy was 29.03 for PHM and 31.04 for CHM and the majority of them were between 20-40 years, Hasanyadeh et al, 2013 showed similar range, ${ }^{10}$ while others showed reverse range results. ${ }^{11,12}$ All full term placenta specimens showed negative p53 immunostaining in all components of villi while the first trimester abortions showed mild positive nuclear p53 immunostaining of all villous components with a $\mathrm{LI}=11.2,6 \cdot 6,4.7$ in cytotrophoblasts, syncytiotrophoblastsand stromal cells respectively. This indicated that p53 plays a role in apoptosis but not normal as apoptotic proteins. Chen et al., 2011 also observed a positive p53 immunoexpression in the nuclei of cytotrophoblast cells and intermediate trophoblasts of abortions and no p53 expression was seen in normal placenta. ${ }^{13}$ While another study showed a negative p53 immunoexpression in syncytiotrophoblasts with a few positivity in cytotrophoblasts in abortions. ${ }^{14}$ In molar villous trophoblastic diseases, P53 LI was

Table 5: Statistical analysis to compare p53 expression between abortion and PHM, abortion and CHM, PHM and CHM.

\begin{tabular}{|c|c|c|c|c|c|c|c|c|c|}
\hline \multirow[b]{2}{*}{$\begin{array}{l}\text { Type of } \\
\text { lesion }\end{array}$} & \multicolumn{2}{|c|}{ Cytotrophoblasts } & \multirow[b]{2}{*}{$\begin{array}{c}P \\
\text { value }\end{array}$} & \multicolumn{2}{|c|}{ syncytiotrophoblast } & \multicolumn{4}{|c|}{ Stromal cells } \\
\hline & $\begin{array}{l}+ \text { ve } \\
\text { No.(\%) }\end{array}$ & $\begin{array}{c}-\mathrm{ve} \\
\text { No.(\%) }\end{array}$ & & $\begin{array}{l}+\mathrm{ve} \\
\text { No.(\%) }\end{array}$ & $\begin{array}{c}-v e \\
\text { No.(\%) }\end{array}$ & $\begin{array}{c}P \\
\text { value }\end{array}$ & $\begin{array}{c}+\mathrm{ve} \\
\text { No.(\%) }\end{array}$ & $\begin{array}{c}\text {-ve } \\
\text { No.(\%) }\end{array}$ & $\begin{array}{c}P \\
\text { value }\end{array}$ \\
\hline $\begin{array}{l}\text { Abortion } \\
\text { PHM }\end{array}$ & $\begin{array}{c}6(40) \\
19(79.17)\end{array}$ & $\begin{array}{c}9(60) \\
5(20.83)\end{array}$ & 0.0190 & $\begin{array}{c}3(20) \\
13(54.17)\end{array}$ & $\begin{array}{c}12(80) \\
11(45.83)\end{array}$ & 0.0485 & $\begin{array}{c}2(13.33) \\
12(50)\end{array}$ & $\begin{array}{c}13(86.67) \\
12(50)\end{array}$ & 0.0378 \\
\hline $\begin{array}{l}\text { Abortion } \\
\mathrm{CHM}\end{array}$ & $\begin{array}{c}6(40) \\
24(100)\end{array}$ & $\begin{array}{l}9(60) \\
0(0)\end{array}$ & $<0.0001$ & $\begin{array}{c}3(20) \\
24(100)\end{array}$ & $\begin{array}{c}12(80) \\
0(0)\end{array}$ & $<0.0001$ & $\begin{array}{l}2(13.33) \\
24(100)\end{array}$ & $\begin{array}{c}13(86.67) \\
0(0)\end{array}$ & $<0.0001$ \\
\hline $\begin{array}{l}\text { PHM } \\
\text { CHM }\end{array}$ & $\begin{array}{c}19(79.17) \\
24(100)\end{array}$ & $\begin{array}{c}5(20.83) \\
0(0)\end{array}$ & 0.0495 & $\begin{array}{c}13(54.17) \\
24(100)\end{array}$ & $\begin{array}{c}11(45.83) \\
0(0)\end{array}$ & $<0.001$ & $\begin{array}{c}12(50) \\
24(100)\end{array}$ & $\begin{array}{c}12(50) \\
0(0)\end{array}$ & $<0.0001$ \\
\hline
\end{tabular}


https://doi.org/10.15218/zjms.2017.013

higher than that of abortion (i.e. $\geq 10 \%$ ), this is in agreement with Erfanian et al , 2009 who showed that all cases of PHM and $\mathrm{CHM}$ were positive for $\mathrm{P} 53 .^{9}$ The highest p53 LI was in cytotrophoblasts of CHM (71.2) followed by PHM (29.0), the lowest P53 LI was observed in stromal cells of villi in all villous lesion, while P53 LI in syncytiotrophoblasts was in between in both PHM and CHM. Statistically, there was a highly significant difference between $1^{\text {st }}$ trimester abortion and molar villous trophoblastic lesions regarding p53 LI means in all villous component $(P<0.001)$; indicating that P53 LI, especially that of cytotrophoblasts, is the best index in separating these three entities. By taking $10 \%$ as a cut-off value, over expression was seen in $40 \%$ of $1^{\text {st }}$ trimester abortion, $80 \%$ PHM, and $100 \%$ for CHM cases. Other researchers use $10.8 \%$ as a cut off value for positive p53 protein immunoexpression. $^{7}$ Petignat et al., 2006 was in agreement with our result in which he found p53 overexpression in HM cases $(93 \%$ of $\mathrm{CHM}$ and $80 \%$ of $\mathrm{PHM})$ in cytotrophoblasts as compared with normal trophoblast; but focally expressed in syncytiotrophoblasts. $^{15}$ Also Al-Bozom, 2000 showed overexpression of p53 in $93 \%$ of $\mathrm{CHM}$ and $57 \%$ of PHM cases while none of non-molar pregnancies express p53. ${ }^{16}$ Halperin et al., 2000 showed p53 overexpression in nuclei of villous trophoblast in all samples of $\mathrm{CHM}$, $50 \%$ of $\mathrm{PHM}$ and $30 \%$ of normal placenta cases. ${ }^{17}$ Chen et al., 2011 found the +ve rate of p53 expression in PHM and CHM were $60.9 \%$ and $85.0 \%$ respectively..$^{11}$ P53 immunoreactivity in abortion was +ve in $40 \%$ of cases in cytotrophoblasts. In PHM more than half of the cases $(79.17 \%)$ were +ve in cytotrophoblasts while all cases of CHM were +ve (100.0\%) in cytotrophoblasts. Hussein, 2009 showed that p53 expression was absent in the first trimester pregnancy termination and PHM whereas there was moderate nuclear positivity in $\mathrm{CM}^{18}$ There was statistically significant difference in p53 immunoexpression in all villous components (cytotrophoblasts, syncytiotrophoblasts and stromal cells) between abortion and PHM, abortion and $\mathrm{CHM}$ and between PHM and CHM. According to the present results, P53 overexpression was useful in separating abortion from $\mathrm{CHM}$ and $\mathrm{PHM}$, and between CHM and PHM. Kale et al., 2001 showed the same as overexpression of p53 was significantly higher in molar placenta than in non-molar $(P<0.0001)$ and there was significant differences in p53 expression between subtypes of molar pregnancy $(P<0.05){ }^{19}$ Other studies found the same with the conclusion that P53 can be used to differentiate between abortion and GTD and subtypes of molar pregnancy. 13,20,21 Yazaki et al, 2006 showed that there is statistically a significance difference between patients of $\mathrm{HM}$, patient progress to GTN or spontaneous abortion regarding the p53 immunoexpression $P<0.05{ }^{7}$ Other studies had investigated other tumor suppressor protein such as P63 (which is a p53 homologue) and found -ve p63 expression in cytotrophoblasts, syncytiotrophoblasts in all cases of abortion and +ve expression in all cases of $\mathrm{PHM}$ and $\mathrm{CHM}^{9,22}$

\section{Conclusion}

p53 immunoexpression was valuable in differentiation between molar and non molar pregnancies and between subtypes of molar pregnancies.

\section{Conflicts of interest}

The authors report no conflicts of interest.

\section{References}

1. Hextan YS, Michael J, Ross S, Yang X, François G, Sekharan PK, et al. Update on the diagnosis and management of gestationaltrophoblastic disease. IJGO 2015; 132:123-6.

2. Clement PB, Young RH. Trophoblastic lesions, miscellaneous primary uterine neoplasms, hematopoietic neoplasms, and metastatic neoplasms to the uterus. In: Clement PB, Young RH, editors. Atlas of Gynecologic Surgical Pathology. 3rd ed. Oxford: Saunders, Elsevier Inc; 2014. p. 284-310. 
3. Merchant $\mathrm{SH}$, Amin MB, Viswanatha DS, Malhotra RK, Moehlenkamp C, Joste NE. P57kip2 Immunohistochemistry in early molar pregnancies: Emphasis on its complementary role in the differential diagnosis of hydropicabortuses. Human Pathol 2005; 36:180-6.

4. Fukunaga M, Katabuchi $H$, Nagasaka T, Mikami $Y$, Minamiguchi S, Lage JM. Interobserver and intraobserver variability in the diagnosis of hydatidiform mole. Am J Surg Pathol 2005; 29:942 -7 .

5. Etebary M, Jahanzadl ,Mohagheghi MA, Azizi E. Immunohistocmechemical analysis of p53 and its correlation to the other prognositic factors in breast cancer. Acta Medica Iranica 2002; 40(2):88 -94 .

6. Srendini ST, Zerbin MCN, Latorre MR, Alves VAF. p53 as aprognostic factor in adrenocortical tumors of adults and children. Braz J Med Biol Res 2003; 36:23-7.

7. Yazaki-Sun S, Daher S, de Souza Ishigai MM, Alves MT, Mantovani TM, Mattar R. Correlation of c-erbB-2 oncogene and p53 tumor suppressor gene with malignant transformation of hydatidiform mole. J Obstet Gynaecol Res 2006; 32:265-72.

8. Hsu SM, Raine L, Fanger $H$. Use of avidin-peroxidase coplex (ABO) in immunoperoxidasetechniques:a comparison between $A B C$ and unlabeled antibody (PAP) procedures. J Histochem Cytochem 1981; 29:577 -80 .

9. Erfanan M, Sharifi N, Omidi AA. p63 and $\mathrm{Ki}-67$ expression in trophoblastic disease and spontaneous abortion; JRMS 2009; 14(6):375-84.

10. Hasanzadeh $M$, Sharifi N, Esmaieli H, Daloee MS, Tabari A. Immunohistochemical expression of the proliferative marker Ki67 in hydatidiform moles and its diagnostic value in the progression to gestational trophoblastic neoplasoia. J Obstet Gynaecol 2013; 39(2):572-7.

11. Sebire NJ, Rees $H$. Diagnosis of gestational trophoblastic disease in early pregnancy. Current Diagnostic Pathology 2002; 8(6):430-40.

12. Nizam K, Haidar G, Memon N, Haidar A. Gestational Trophoblastic Disease: Experience at Nawabshah Hospital. JAyub Med Coll 2009; 21:67-9.

13. Chen $Y X$, Shen DH, Gu YQ, Zhong PP, Xie JL, Song QJ, et al. Immunohistochemistry of p57 and p53 protein in differential diagnosis of hydropic abortion, partial and complete hydatidiform mole. Zhonghua Bing Li XueZaZhi 2011; 40(10):694700 .

14. Ichikawa $\mathrm{N}$, Zhai $\mathrm{YL}$, ShiozawaT, Toki $\mathrm{T}$, Nouguchi $H$, Nikaido $T$, et al. Immunohistochemical Analysis Of Cell Cycle Regulatroy Gene Products in normal Trophoblast and Placental site Trophoblastic Tumor. Int J Gynaecol Pathol 1998; 17(3):235-40.
15. Petigant $P$,Laurini R, Goffin F, Bruchim I, Bischof $P$. Expression of matrix metalloproteinase-2 and mutant p53 is increased in hydatiform mole as compared with normal placenta. Int J Gynecol Cancer 2006; 16(4):1679-84.

16. Al-Bozom IA. p53 and bcl2 oncoprotein expression in placentas with hydropic changes and partial and complete moles. APMIS 2000; 108:756-60.

17. Halperin R, Peller S, Sandbank J, Bukovsky I, Schneider D. Expression of p53 Gene and Apoptosis in Gestational Trophoblastic Disease. Placenta 2000; 21:58-62.

18. Hussein MR. Analysis of p53, Bcl2 and epidermal growth factor receptor protein expression in the partial and complete hydatiform moles. Exp Mol Pathol 2009; 87(1):63-9.

19. Kale A, Soylemez F, EnsariA. Expression of proliferation marker (ki-67, proliferating cell nuclear antigen, and silver staining nuclear organizer regions) and of p53 tumor protein in gestational trophoblastic disease. Am J Surg Pathol 2001; 33:176-85.

20. UzunlarAK, YilmazF, Bayhan G, Akkus Z. Expression of $\mathrm{p} 53$, proliferation cell nuclear antigen, and ki-67 in gestational trophoblastic disease. Eur J Gynaecol Oncol 2002; 23:79-83.

21. Chen $Y$, Shen D, Gu Y, Zhong P, Xie J, Song Q. The Diagnostic value of $\mathrm{Ki}-67, \mathrm{p} 53$, and p63 in distinguishing partial HM from hydropic abortion. Wien Klin Wochenschr 2012: 124:184-7.

22. Shih IM, Kurman RJ. P63 expression is useful in distinction of epithelioid trophoblastic and placental site trophoblastic tumors by profiling trophoblastic subpopulations. Am J Surg Pathol 2004; 28(9):1177-83. 